\title{
Examining How Environmental Concern Affects Purchase Intention: Mediating Role of Perceived Trust and Moderating Role of Perceived Risk
}

\author{
Man-Lung Jonathan Kwok \\ The Hong Kong Polytechnic University \\ Email: spjonk@speed-polyu.edu.hk \\ Mei-Chi Macy Wong \\ The Hong Kong Polytechnic University \\ Email: spmacy@speed-polyu.edu.hk \\ Mei Mei Lau \\ The Hong Kong Polytechnic University \\ Email: spmay@speed-polyu.edu.hk
}

\begin{abstract}
The aim of this study was to explore the factors affecting the intention to purchase PCTG plastic water bottles. It further elaborates on the relationships among perceived value, perceived risk, trust in the quality of the product, and purchase with the concern of protecting the environment. Another focus of this research was to measure the mediating effect of trust on the relation between perceived value and purchase intention and to test whether perceived risk has any moderating effect on the relation between perceived value and purchase intention. Three hundred valid responses from Hong Kong consumers were used to test the mediation-moderation model. The research findings indicated that trust partially mediates the significant relationship of perceived value with purchase intention. The moderating role of perceived risk was also found to have significant effect on the direct effect between perceived value and purchase intentions, indicating that the relationship between the perceived value and purchase intention is stronger under high perceived risk rather than under low perceived risk. Managerial implications and limitations are also discussed.
\end{abstract}


Keywords: Perceived Value, Perceived Risk, Trust, Purchase Intention, Environmental Concern

\section{INTRODUCTION}

In recent years, due to the rising customer concern in sustainable environment, many companies have integrated the concepts of green marketing into all aspects of their routine marketing activities, focusing on developing, differentiating, pricing, and promoting products and services (Chen \& Chang, 2013; Ottman, 1992). Indeed, many companies have begun to engage in green marketing activities that trigger and sustain consumers' environmental attitudes and behaviors (Jain \& Kaur, 2004). Firms use green marketing strategies to gain various financial benefits through capturing the green opportunities in the market (Chen, 2008). On the other hand, consumers are also eager to purchase more products that are environmental friendly (Kalafatis \& Pollard, 1999).

In relation to green marketing, Chen (2010) conducted a study to develop multiple constructs of purchase intention, which are worth exploring and developing. Therefore, this study aimed to develop a framework related to PCTG (PolyCyclohexylendimethylene Terephthalate Glycol) plastic water bottle made from durable and heat resistant materials designed for reusable purpose. The main research question of this study is, "What factors affect the purchase intentions of PCTG plastic water bottle?" The hypothesized model is depicted in Figure 1.

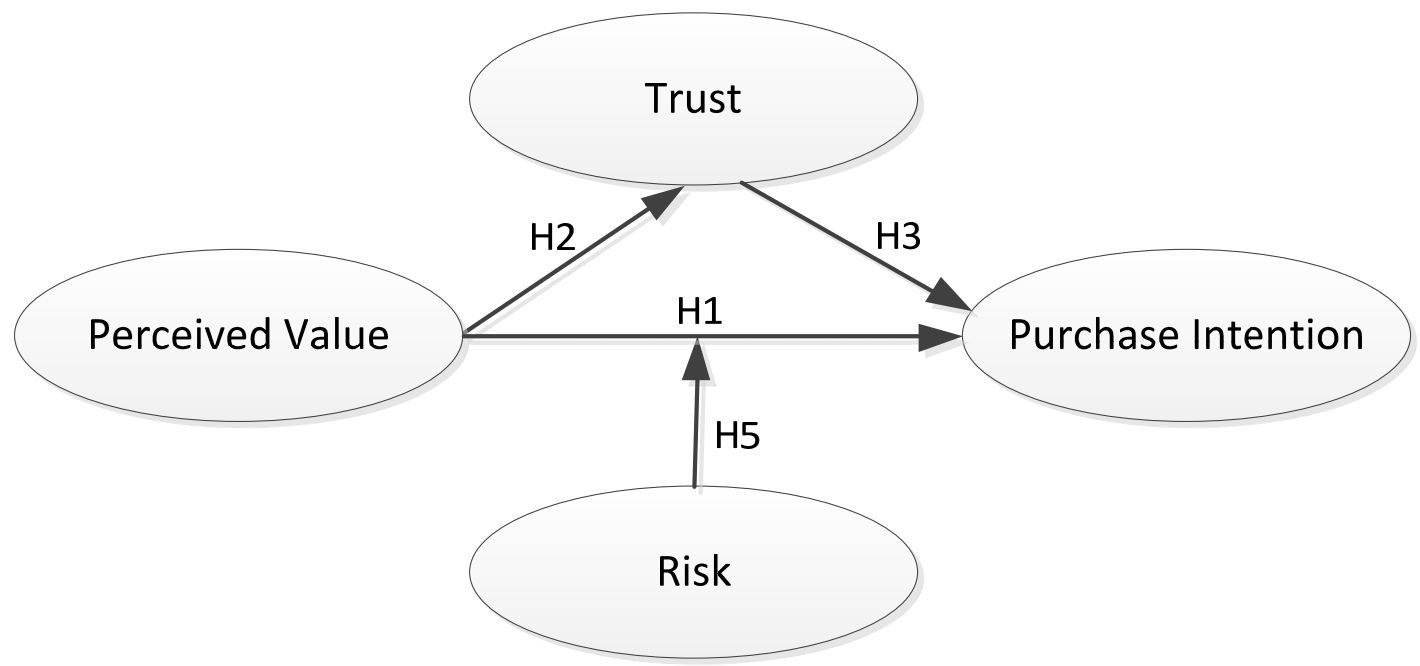

Figure 1 Hypothesized Model of the Study 


\section{LITERATURE REVIEW AND HYPOTEHSES DEVELOPMENT}

\section{Perceived Value and Purchase Intention}

Previous research has found a positive effect of perceived value on marketing performance (Sweeney et al., 1999); thus, it is important for companies to increase the perceived value of products in order to enhance consumer purchase intentions (Steenkamp \& Geyskens, 2006). Perceived value in this study is defined as "a consumer's overall appraisal of the net benefit of a product or service between what is received and what is given based on the consumer's environmental desires, sustainable expectations, and green needs" (Chen \& Chang, 2012, p. 505). Indeed, perceived value has been found to affect purchase intentions (Zeithaml, 1988). Purchase intentions, as defined in Netemeyer, Maxham, and Pullig (2005) and Morrison (1979), refer to "the likelihood that a consumer would buy a particular product resulting from his or her environmental needs". Based on the discussion, it is hypothesized that:

H1: Perceived value is positively related to purchase intentions.

\section{Perceived Value and Trust}

Trust is the level of willingness to depend on an object based on the expectation of its ability, reliability (Ganesan, 1994; Hart \& Saunders, 1997), and the intention to accept vulnerability due to the positive expectations of the integrity and capability of another object (Lin et al., 2003; Rousseau et al., 1998). Similarly, Chen (2010) defined trust related to environmental concern as "a willingness to depend on one object based on the belief or expectation resulting from its credibility, benevolence, and ability about environmental performance". Therefore, when the perceived value of a product is high, consumers are more likely to rely on it and trust its attributes. Past research studies (e.g., Chen \& Chang, 2012; Eid, 2011; Sweeney et al., 1999) have found a positive relationship between perceived value and trust, and thus, we developed the following hypothesis:

$\mathrm{H} 2$ : Perceived value is positively related to trust.

\section{Trust and Purchase Intention}

Trust is the confidence that another party will behave as expected (Hart \& Saunders, 1997). Thus, higher consumer trust leads to higher purchase intention (Harris \& Goode, 2010). Past literature has provided empirical evidence to support this relationship (Schlosser et al., 2006); hence: 
H3: Trust is positively related to purchase intention.

\section{Mediating Effect of Trust on the relation between Perceived Value and Purchase Intention}

When a consumer trusts the attributes of a product in terms of its reliability, ability, and benevolence, purchase intentions will be enhanced. The value given to the product can trigger trust. If one values the products, the expectation of, belief in, and subsequently trust in a product will increase. Therefore, higher value will lead to higher trust and consequently to higher purchase intentions.

H4: Trust mediated the direct relationship between perceived value and purchase intentions.

\section{Moderating Effect of Risk}

Risk exists in any purchases due to asymmetrical information (Mishra et al., 1998). Since this happens under uncertainty, it would also affect purchase decision of the consumers (Aaker, 1996). Empirically, the existing findings support the negative association of perceived risk with consumer purchase decisions and behaviors (Mitchell, 1999). Some sellers may use the asymmetrical information to act dishonestly and take advantage of the consumers (Gregg \& Walczak, 2008). If the consumer perceives high risks of the product quality, they would not trust and subsequently buy the product (Mitchell, 1999).

The perception of higher risk will negatively affect the existing relationship between value and purchase intentions. Thus, the positive relationship between value and purchase intentions will be reduced. Accordingly, we proposed the following moderating hypothesis:

H5: Under high (instead of low) risk situation, the positive relationship of perceived value and purchase intentions will be reduced (instead of enhanced), and vice versa.

\section{RESEARCH METHOD}

\section{Sampling and Data Collection}

The data was collected randomly using online questionnaire. The respondents had to be the consumers who have knowledge of and experience with buying or using PCTG water bottles. Altogether, 590 questionnaires were sent to the consumers and 300 valid responses were collected, resulting in $50.8 \%$ response rate. 
The average variance extracted (AVE) was used to analyze the data to examine the convergent and discriminant validity. To test the proposed mediation-moderation model, SPSS Macro (PROCESS) (Hayes, 2013) was adopted.

\section{Measures}

All the measures were adapted from previous studies. To capture the focus of this study, we changed the focal wordings in each item to PCTG plastic water bottle. A simple pilot test was conducted to check whether the items were easy to understand.

All of the items were measured on a 5-point Likert scale, where 1 represents "strongly disagree" and 5 represents "strongly agree". Perceived value was adapted from the 5-item scale developed by Patterson and Spreng (1997). Five-item scale of trust was adapted from Chen's (2010) study. Three items measuring purchase intentions were adapted from Pavlou (2003) and Chang and Chen (2008). Finally, risk comprised 5 items adapted from Jacoby and Kaplan (1972), Murphy and Enis (1986), and Sweeney et al. (1999).

\section{RESULTS}

\section{Descriptive Statistics, Correlation, Convergent Statistics and Discriminant Statistics}

The sample comprised $34 \%$ of males and $66 \%$ of females. Most of the respondents $(85 \%)$ were 19 to 29 years old. The convergent validity (as shown by AVE) and discriminant validity were in the acceptable range. Table 1 shows the results of bivariate correlations among the constructs and the reliabilities.

Table 1 Bivariate Correlations and Reliabilities of Constructs

\begin{tabular}{|l|c|c|c|c|c|c|}
\hline & $\mathrm{M}$ & $\mathrm{SD}$ & 1 & 2 & 3 & 4 \\
\hline 1. Perceived value & 3.87 & 0.69 & $(.82)$ & & & \\
\hline 2. Trust & 3.58 & 0.69 & $.64^{* *}$ & $(.91)$ & & \\
\hline 3. Purchase intention & 3.85 & 0.84 & $.53^{* *}$ & $.60^{* *}$ & $(.93)$ & \\
\hline 4. Risk & 2.96 & 0.98 & -.38 & -.84 & -.00 & $(.92)$ \\
\hline
\end{tabular}

Note: Reliabilities are in parentheses

$$
* * \mathrm{p} \leq .01
$$




\section{Hypotheses Results}

Table 2 shows regression results of Hypothesis 1 to Hypothesis 5.

Based on Model 2 in Table 2, Hypotheses 1, 2, and 3 were supported (H1: $\beta$ $=.32, p<.0001 \mathrm{H} 2: \beta=.64, p<.0001 ; \mathrm{H} 3: \beta=.53, p<.0001)$.

We evaluated the upper and lower confidence interval to assess the indirect effect proposed in the Hypothesis 4(Hayes, 2013). The lower confidence interval and the upper confidence interval were .25 and .44 , respectively, supporting Hypothesis 4 .

Model 2 in Table 2 also supported the moderating hypothesis (Hypothesis $5 ; \beta$ $=.15, p<.001)$. We examined the slope to further understand the interaction effect (Figure 2).

According to the figure, the results contradict our hypothesis. The figure shows that high perceived value is associated with higher purchase intention in high risk situation. Therefore, this result contradicts the Hypothesis 5.

Table 2 Results of Regression Analysis Mediated Moderation

$(\mathrm{N}=300)$

\begin{tabular}{|c|c|c|}
\hline & Model 1 & Model 2 \\
\hline Variables & Trust & Purchase intentions \\
\hline \multicolumn{3}{|l|}{ Direct effects } \\
\hline Perceived value & $.64 * * *$ & $.32 * * *$ \\
\hline Trust & & $.53 * * *$ \\
\hline Risk & & .02 \\
\hline Perceived value $\mathrm{x}$ risk & & $.15 * *$ \\
\hline$\Delta \mathrm{R}^{2}$ & & .0053 \\
\hline Overall $\mathrm{R}^{2}$ & .41 & .41 \\
\hline Overall model F & $204.00 * * *$ & $51.61 * * *$ \\
\hline
\end{tabular}

Note: Standardized regression coefficients are shown

$$
* * \mathrm{p}<.001, * * * \mathrm{p}<.0001 .
$$




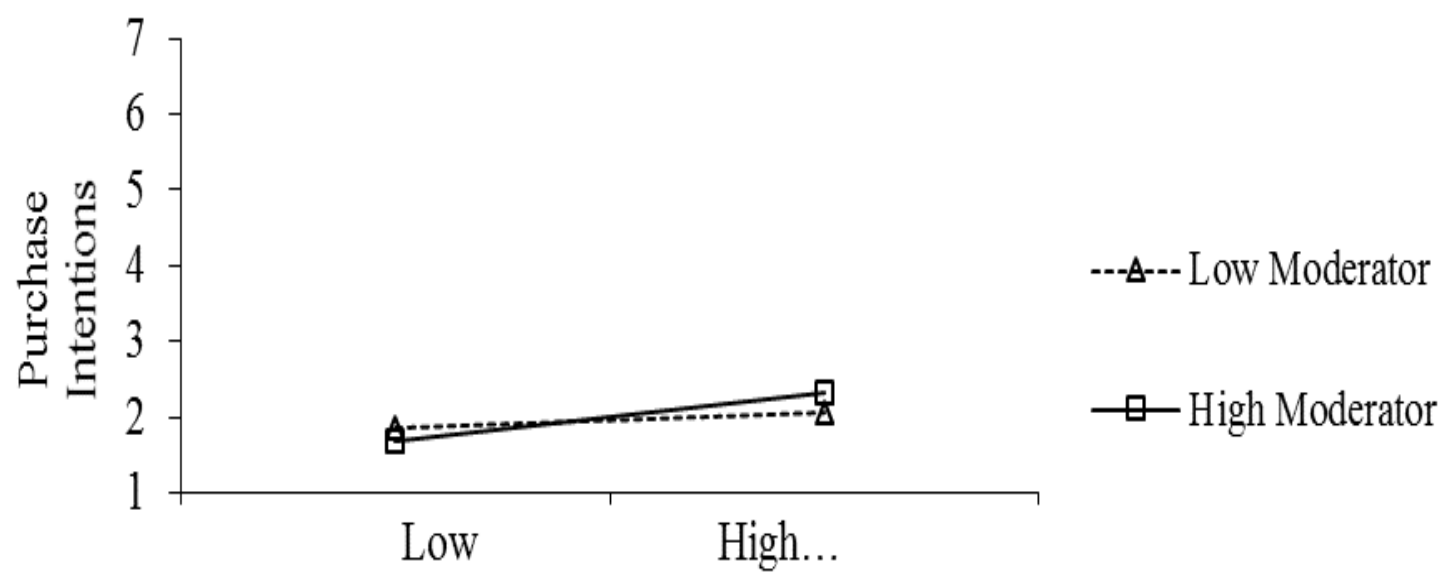

Figure 2 Slope Test of Interaction Effect

\section{DISCUSSION AND CONCLUSION}

Generally, all of the results are consistent with the previous research findings, suggesting that perceived value is positively related to purchase intention and trust; trust is positively related to purchase intentions; and trust mediates the direct positive effect of perceived value and purchase intentions.

However, the most surprising result of this study is that risk does not affect purchase intentions on the condition that perceived value is high enough overcome the negative effect of risk. Indeed, some previous research has supported the assumption that risk is valued (e.g., Lamm, Schaude, \& Trommsdorff, 1971; Olson \& Suls, 2000). Risk is valued because many individuals believe that the society appreciates and rewards the risk-taking behavior (Muuss \& Porton, 1998). Therefore, in our study, respondents may have been affected by their perception that risk-taking behavior is rewarded, which increased the value of risk and in return led to higher intentions to purchase environmentally friendly goods.

\section{Practical Implications}

Marketers should emphasize the benefits and values of environmental friendly products through marketing communication. Since products that are environmental friendly are usually more expensive compared to conventional products, perceived risks cannot be avoided in the buying process. However, a message that would encourage risk-taking behavior can be included in their promotional items to counterbalance the negative effect of risk. 


\section{Future Research}

The perception of risk is subject to the environment and personalities of the consumers. Future research can try to investigate the environmental conditions and personality of the consumers that are likely to encourage the risk-taking behavior, which would allow marketers to target specific consumers in a more effective way.

\section{REFERENCES}

Aaker, D.A. (1996). Building strong brands. Free Press, New York.

Chang, H.H. \& Chen, S.W. (2008). The impact of online store environment cues on purchase intention: trust and perceived risk as a mediator. Online Information Review, 32(6), 818-841. http://dx.doi.org/10.1108/14684520810923953

Chen, Y.S. (2008). The driver of green innovation and green image - green core competence. Journal of Business Ethics, 81(3), 531-543. http://dx.doi.org/10.1007/s10551-007-9522-1

Chen, Y.S. (2010). The drivers of green brand equity: Green brand image, green satisfaction, and green trust. Journal of Business Ethics, 93(2), 307-319. http://dx.doi.org/10.1007/s10551-009-0223-9

Chen, Y.S. \& Chang, C.H. (2012). Enhance green purchase intentions: The roles of green perceived value, green perceived risk, and green trust. Management Decision, 50(3), 502-520. http://dx.doi.org/10.1108/00251741211216250

Chen, Y.S. and Chang, C.H. (2013). Towards green trust: The influences of green perceived quality, green perceived risk, and green satisfaction. Management Decision, 51(1), 63-82. http://dx.doi.org/10.1108/00251741311291319

Eid, M.I. (2011). Determinants of e-commerce customer satisfaction, trust, and loyalty in Saudi Arabia. Journal of Electronic Commerce Research, 12(1), 78-93.

Ganesan, S. (1994). Determinants of long-term orientation in buyer-seller relationships. Journal of Marketing, 58(2), 1-19. http://dx.doi.org/10.2307/1252265

Gregg, D.G. \& Walczak, S. (2008). Dressing your online auction business for success: An experiment comparing two e-Bay businesses. MIS Quarterly, 32(3), 653-670.

Harris, L.C. \& Goode, M.M.H. (2010). Online service scapes, trust, and purchase intentions. Journal of Services Marketing, 24(3), 230-243. http://dx.doi.org/10.1108/08876041011040631

Hart, P. \& Saunders, C. (1997). Power and trust: Critical factors in the adoption and use of electronic data interchange. Organizational Science, 8(1), 23-42. http://dx.doi.org/10.1287/orsc.8.1.23 
Hayes, A.F. (2013). Introduction to mediation, moderation, and conditional process analysis. The Guilford Press, New York.

Jacoby, J. \& Kaplan, L.B. (1972). The components of perceived risk, in Proceedings of the Third Annual Conference, Venkatesan, M. ed., Association for Consumer Research, Iowa City.

Jain, S.K. and Kaur, G. (2004). Green marketing: An Indian perspective. Decision, 31(2), 168-209.

Kalafatis, S.P. \& Pollard, M. (1999). Green marketing and Ajzen's theory of planned behavior: A cross-market examination. Journal of Consumer Marketing, 16(5), 441-460. http://dx.doi.org/10.1108/07363769910289550

Lamm, H., Schaude, E., \& Trommsdorff, G. (1971). Risk shift as a function of group members' value of risk and need for approval. Journal of Personality and Social Psychology, 20(3), 430-435. http://dx.doi.org/10.1037/h0031937

Lin, N.P., Weng, J.C.M. \& Hsieh, Y.C. (2003). Relational bonds and customer's trust and commitment: A study on the moderating effects of web site usage. Service Industries Journal, 23(3), 103-124. http://dx.doi.org/10.1080/714005111

Mishra, D.P., Heide, J.B. \& Cort, S.G. (1998). Information asymmetry and levels of agency relationships. Journal of Marketing Research, 35(3), 277-295. http://dx.doi.org/10.2307/3152028

Mitchell, V.W. (1999). Consumer perceived risk: Conceptualizations and models. European Journal of Marketing, 33(1), 163-195. http://dx.doi.org/10.1108/03090569910249229

Morrison, D.G. (1979). Purchase intentions and purchase behavior. Journal of Marketing, 43(2), 65-74. http://dx.doi.org/10.2307/1250742

Murphy, P.E. \& Enis, B.M. (1986). Classifying products strategically. Journal of Marketing, 50(3), 24-42. http://dx.doi.org/10.2307/1251583

Muuss, R. E., \& Porton, H. D. (1998). Increasing risk behavior among adolescents. In R. E. Muuss \& H. D. Porton (Eds.), Adolescent behavior and society: A book of readings (5th ed., pp. 422-431). New York: McGraw-Hill.

Netemeyer, R.G., Maxham, J.G. \& Pullig, C. (2005). Conflicts in the work-family interface: links to job stress, customer service employee performance, and customer purchase Intent. Journal of Marketing, 69(2), 130-143. http://dx.doi.org/10.1509/jmkg.69.2.130.60758

Olson, B. D., \& Suls, J. (2000). Self-, other-, and Ideal-judgments of risk and caution as a funtion of the five-factor model of personality. Personality and Individual Differences, 28(3), 425-436. http://dx.doi.org/10.1016/S0191-8869(99)00105-1 
Ottman, J.A. (1992). Green marketing, NTC Business Books, Chicago, IL.

Patterson, P. \& Spreng, R. (1997). Modeling the relationship between perceived value, satisfaction and repurchase intention in a business-to-business, service context: An empirical examination. International Journal of Service Industry Management, 8(5), 414-434. http://dx.doi.org/10.1108/09564239710189835

Pavlou, P.A. (2003). Consumer acceptance of electronic commerce: Integrating trust and risk with the technology acceptance model. International Journal of Electronic Commerce, 7(3), 101-134.

http://dx.doi.org/10.1080/10864415.2003.11044275

Rousseau, D.M., Sitkin, S.B., Burt, R.S. \& Camerer, C. (1998). Not so different after all: A cross-discipline view of trust. Academy of Management Review, 23(3), 393-404. http://dx.doi.org/10.5465/AMR.1998.926617

Schlosser, A.E., White, T.B. \& Lloyd, S.M. (2006). Converting web site visitors into buyers: How web site investment increases consumer trusting beliefs and online purchase intentions. Journal of Marketing, 70(2), 133-148. http://dx.doi.org/10.1509/jmkg.70.2.133

Steenkamp, J.B.E.M. and Geyskens, I. (2006). How country characteristics affect the perceived value of web stes. Journal of Marketing, 70(3): 136-150. http://dx.doi.org/10.1509/jmkg.70.3.136

Sweeney, J.C., Soutar, G.N. \& Johnson, L.W. (1999). The role of perceived risk in the quality-value relationship: A study in a retail environment. Journal of Retailing, 75(1), 77-105. http://dx.doi.org/10.1016/S0022-4359(99)80005-0

Zeithaml, V.A. (1988). Consumer perceptions of price, quality, and value: A meansend ) model and synthesis of evidence. Journal of Marketing, 52(3), 48-62. 